\title{
JUDICIAL JURISDICTION OVER INTERNET PRIVACY VIOLATIONS AND THE GDPR: A CASE OF "PRIVACY TOURISM"?
}

\author{
by
}

IOANNIS REVOLIDIS

This paper discusses the impact of art. 79(2) of the General Data Protection Regulation (GDPR) in international litigation over online privacy violations. The first part introduces the tendency of the European legislator to treat private international law problems in the field of data protection as isolated and independent from the traditional secondary private international law acts. The second part analyses the current status quo of international jurisdiction over online privacy violations according to Regulation 1215/2012. After briefly examining the eDate and Martinez ruling (joined cases C-509/09 and C-161/10), it concludes that the Court of Justice of the European Union has stretched the jurisdictional grounds of art. 7(2) Regulation 1215/2012 too far in order to afford strong protection to data subjects. In that sense, it raises doubts on whether art. 79(2) was necessary. Following this conclusion, it tries to explore the uneasy relationship of GDPR art. 79(2) with the jurisdictional regime established under Regulation 1215/2012. Instead of an epilogue, the last part tries to make some reflections on the impact of GDPR art. 79(2) in privacy litigation cases involving non-EU parties.

\section{KEY WORDS}

Conflict of Laws, International Jurisdiction, Internet, Data Protection Law, Forum Shopping, Regulation (EU) 2016/679, Regulation 1215/2012

ioannis.revolidis@iri.uni-hannover.de, Ioannis Revolidis has graduated from Faculty of Law, Aristotle University of Thessaloniki, Coordinator of the EULISP Master of Laws in IT/IP Law, research associate, legal and ethical framework of health research projects at Institute for Legal Informatics, Leibnitz, University Hannover. 


\section{INTRODUCTION}

Conflict of laws problems related to data protection have already received a unique treatment from the European legislator during the adoption of the Data Protection Directive. The Data Protection Directive had been prepared during the 1980s and 1990s, namely during a time when the current Internet was still just at the beginning of its creation and of course not widely used. In the historical reality of the Data Protection Directive, the vast amount of international exchanges of personal information were, more or less, a theoretical and mostly unlikely scenario. ${ }^{1}$

Although created in such a historical background, the Data Protection Directive included provisions regulating the law applicable to transnational data flows. These were to be accommodated in article 4(1) of the Data Protection Directive which reads as follows:

"1. Each Member State shall apply the national provisions it adopts pursuant to this Directive to the processing of personal data where: (a) the processing is carried out in the context of the activities of an establishment of the controller on the territory of the Member State; when the same controller is established on the territory of several Member States, he must take the necessary measures to ensure that each of these establishments complies with the obligations laid down by the national law applicable; (b) the controller is not established on the Member State's territory, but in a place where its national law applies by virtue of international public law; (c) the controller is not established on Community territory and, for purposes of processing personal data makes use of equipment, automated or otherwise, situated on the territory of the said Member State, unless such equipment is used only for purposes of transit through the territory of the Community [...]".

By the time of its adoption, article 4(1) covered many legislative gaps within the system of the protection of personal information in the EU. On the one hand, the major concern of the European legislator was to prohibit a situation where a data controller could avoid the implementation of any of the national data protection laws adopted by the Member States. By the time of the adoption of the Directive, the basic

1 See on that Moerel, L. (2011) The long Arm of EU data protection law: Does the Data Protection Directive apply to processing of personal data of EU citizens by websites worldwide? International Data Privacy Law, 1(1) p. 28. 
fear was that a data controller might relocate his/her activities outside of the EU, while still continuing to process personal information of EU citizens. The three indents of art. 4(1) were designed in order to cover the different aspects of that same danger:

- indent a) the situation where the data controller, while having its main seat outside the EU, still actively conducts business with EU citizens through an establishment within the EU,

- indent $b$ ) the situation where the data controller would be established in territories that geographically do not belong to the European continent, but are still controlled by Member States; in that case the directive aimed at clarifying that it will be applicable to the extent that under public international law, the legal order of a Member State would still regulate the issues of that territory,

- indent c) the situation where the data controller, having its main seat outside the EU, would still process personal information of EU citizens by using equipment located within a Member State, without necessarily retaining an establishment in an EU Member State. ${ }^{2}$

On the other hand, art. 4(1), although not primarily an instrument of private international law, de facto obtained such a role within the EU. At the time of its adoption, the basic European instrument regarding the law applicable in European transactions was the Rome Convention of 1980, which only referred to certain contractual obligations without being applicable to problems related to data protection law. Moreover, there was still no unified regime regarding non-contractual obligations, which represented the main corpus of international data flows. Art. 4(1) was thus called upon to determine the law applicable also in cases where the data flows were taking place purely between different Member States of the EU. ${ }^{3}$

The insertion of a specific conflict of laws regime within the Data Protection Directive was a major departure from the principle of country of origin that was predominant at similar legislative initiatives of the EU at the time. ${ }^{4}$ One might find such a departure reasonable if account is to be

2 Moerel, L. (2011) Back to basics: when does EU data protection law apply? International Data Privacy Law, 1(2) pp. 92-110, esp. pp. 94-97, offers a very detailed account of the rationale behind art. 4(1) of the Data Protection Directive. For an early account of the same see Bygrave, L. (2000) Determining Applicable Law pursuant to European Data Protection Legislation. Computer Law E Security Report, 16 ,pp. 252-257. 
taken of the complex and hybrid nature of Data Protection rules, ${ }^{5}$ which is inextricably linked to the very particular nature of data as the subject matter of legal regulation and the subsequent discussion whether data shall be provided for a specific set of rules rather than being covered by pre-existing and non-data specific regulations. ${ }^{6}$

In addition, the adoption of the Data Protection Directive was a step towards an enhanced protection of the fundamental right to privacy; ${ }^{7}$ its adoption was inspired, in other words, from a clear mandate to expand the protection of human rights within the EU. During the same period, it was still open to debate whether EU private international law (both procedural and substantive) was taking a similar direction towards guaranteeing the basic freedoms and rights of EU citizens. ${ }^{8}$ A special conflict of laws regime for data protection law was, thus, probably stemming from the anxiety of the European legislator to guarantee that the strong human rights mandate of the Data Protection Directive would not be compromised by the different priorities of EU private international law.

One can in that context better understand the mandate of art. 4(1)(a): "[...] when the same
controller is established on the territory of several Member States, he must take the necessary
measures to ensure that each of these establishments complies with the obligations laid down
by the national law applicable [...]". It is worth mentioning here that the Article 29 Working
Party has also classified art. 4 as a genuine private international law rule for intra-European
data flows. See WP 56, 30 May 2002, p. 6 where it is stated: "[...] Concerning the situations
within the Community, the objective of the directive is twofold: it aims at avoiding gaps (no data
protection law would apply) and at avoiding multipleldouble application of national laws.
As the directive addresses the issue of applicable law and establishes a criterion for determining
the law on substance that should provide the solution to a case, the directive itself fulfils the role
of a so-called "rule of conflict" and no resource to other existing criteria of international private law
is necessary (emphasis added)".

4 See for example art. 3 of the E-Commerce directive. For an analysis of the functioning of the principle of country or origin in E-Commerce see Savin, A. (2013) EU Internet Law. Cheltenham; Northampton: Edward Elgar, pp. 45-48.

5 Svantesson, D.J.B. (2013) A "layered approach" to the extraterritoriality of data privacy laws. International Data Privacy Law, 3(4) pp. 278-286, concludes that even within the premises of private international law per se, the nature of data protection rules is complicated and suggests that one cannot always cover them with the same conflict of laws rule. He tries, therefore, to classify them in three basic distinct private international law categories and goes on to examine which rules fit the distinct character of different data protection rules better.

6 For a recent debate on the issue, see Woods, A.K. (2016) Against Data Exceptionalism. Stanford Law Review, 68(4) pp. 729-789, who provides some elaborate argumentation against treating data under a data specific legal regime, while Svantesson, D.J.B. (2016) Against "Against Data Exceptionalism". Masaryk University Journal of Law and Technology, 10(2) pp. 200-211, argues for the opposite.

7 See Directive 95/46/EC of the of the European Parliament and of the Council of 24 October 1995 on the protection of individuals with regard to the processing of personal data and on the free movement of such data. Official Journal of the European Union (1995/L 281/31) 23 November. Available from: http://eur-lex.europa.eu/legal-content/EN/TXT/PDF/?uri= CELEX:31995L0046\&from=EN:PDF [Accessed 7 June 2017), recitals 7 and 8. 
In the meantime, though, there has been a clear convergence of the aims of EU private international law and those of the Data Protection Directive. Already during the middle of the previous decade and in the shadow of the discussion for the adoption of a European Constitution, ${ }^{9}$ the Council urged a clear strengthening of the human rights dimension of EU private international law, ${ }^{10}$ while the Lisbon Treaty ${ }^{11}$ signaled the formal adoption of the Charter of the Fundamental Rights as primary EU Law, ${ }^{12}$ a step that radically changed the value system of EU private international law, making the protection of fundamental rights its main priority. ${ }^{13}$

One might, in that sense, argue that EU private international law was, especially after the adoption of the Lisbon Treaty, in a better position

8 The Court of Justice was nonetheless trying already during the 80 s to establish that EU private international law in general and the Brussels Convention in particular were aiming at strengthening the legal protection of EU citizens rather than just promoting the facilitation of the common market. See Duijnstee $v$ Goderbauer [1983], case C-288/82, par. 11-12, where the Court stated: "[...] According to the preamble to the Convention, the Contracting States, anxious to "strengthen in the Community the legal protection of persons therein established", considered that it was necessary for that purpose "to determine the international jurisdiction of their courts, to facilitate recognition and to introduce an expeditious procedure for securing the enforcement of judgments, authentic instruments and court settlements". Both the provisions on jurisdiction and those on the recognition and enforcement of judgments are therefore aimed at strengthening the legal protection of persons established in the Community [... $]^{\prime \prime}$.

9 For the background of this initiative see Pache, E. (2002) Eine Verfassung für Europa Krönung oder Kollaps der europäischen Integration? Europarecht, 37 pp. 767-784.

10 As it has been documented in the Council's Hague Programme: Strengthening Freedom, Security and Justice in the EU. Official Journal of the European Union, (2005/C 53/1) 03 March. Available from: http://eur-lex.europa.eu/legal-content/EN/TXT/PDF/?uri=CELEX:52005X G0303(01)\&from=EN:PDF [Accessed 7 June 2017], p. 2: "[...] Fundamental rights, as guaranteed by the European Convention on Human Rights and the Charter of Fundamental Rights in Part II of the Constitutional Treaty, including the explanatory notes, as well as the Geneva Convention on Refugees, must be fully respected. At the same time, the programme aims at real and substantial progress towards enhancing mutual confidence and promoting common policies to the benefit of all our citizens. Incorporating the Charter into the Constitutional Treaty and accession to the European Convention for the protection of human rights and fundamental freedoms will place the Union, including its institutions, under a legal obligation to ensure that in all its areas of activity, fundamental rights are not only respected but also actively promoted [...]".

11 For a general account on the impact of the Lisbon Treaty on the Institutional values of the EU, see among others Dougan, M. (2008) The Treaty of Lisbon 2007: Winning Minds not Hearts. Common Market Law Review, 45(3) pp. 617-703, Harpaz, G. and Herman, L. (2008) The Lisbon Reform Treaty: Internal and External Implications. European Journal of Law Reform, 10(4) pp. 431-436, Terhechte, J.P. (2008) Der Vertrag von Lissabon: Grundlegende Verfassungsurkunde der europäischen Rechtsgemeinschaft oder technischer Änderungsvertrag? Europarecht, 43 pp. 143-190, Pech, L. (2011) The Institutional Development of the EU Post - Lisbon: A case of plus ca change...?, UCD Dublin European Institute Working Paper 11 - 5, December 2011, Goebel, R.J. (2011) The European Union and the Treaty of Lisbon. Fordham International Law Journal, 34(5) pp. 1251-1268.

12 For the importance and impact of the primary EU status awarded to the Charter under the Lisbon Treaty see Landau, E.C. (2008) A New Regime of Human Rights in the EU? European Journal of Law Reform, 10(4) pp. 557 - 575, Pache, E. and Rösch, F. (2009) Die neue Grundrechtsordnung der EU nach dem Vertrag von Lissabon. Europarecht, 44 pp. 769 - 790, Lanaerts, K. (2012) Die EU - Grundrechtecharta: Anwendbarkeit und Auslegung. Europarecht, 47 pp. 3 - 18, Sarmiento, D. (2013) Who's afraid of the Charter? The Court of Justice, National Courts and the new Framework of Fundamental Rights Protection in Europe. Common Market Law Review, 50(3) pp. 1267-1304. 
to accommodate the protection of personal data in cases of international data flows in a more comprehensive way. ${ }^{14}$

Such a line of thinking was not convincing either for the Court of Justice, which in the recent VKI $v$. Amazon case $^{15}$ confirmed the special role of art. 4(1) in determining the law applicable to a certain data processing activity independently from any stipulations found in the Rome I and II Regulations, ${ }^{16}$ or for the European legislator, who isolated the private international law regime of EU Data Privacy law even further. Art. 3 of the General Data Protection Regulation (GDPR) is the spiritual successor of art. 4 of the Data Protection Directive, while art. 79(2) of the GDPR, which lies in the center of this contribution, is a novelty in terms of defining the judicial jurisdiction over violations of data protection law. Instead of leaving the issues of judicial jurisdiction to be determined by the Brussels Ia Regulation and the principles developed over the past decades from the Court of Justice in interpreting the latter, the GDPR went as far as to create a special jurisdictional regime for data privacy disputes.

13 See the priorities set by the The Stockholm Programme - An open and secure Europe serving and protecting citizens. Official Journal of the European Union (2010/C 115/1) 05 May. Available from: http://eur-lex.europa.eu/legal-content/EN/TXT/PDF/?uri=OJ:C:2010:115: FULL\&from=en:PDF [Accessed 7 June 2017] p. 4, as well as the EU Justice Agenda for 2020, $\mathrm{COM}(2014) 144$ final.

14 Starting as early as the Brussels Convention of 1967, one might argue that EU private international law has accumulated a non-negligible experience in dealing with the crossborder dimension of the protection of fundamental rights.

15 Verein für Konsumenteninformation v. Amazon [2016], Case C-191/15.

16 Verein für Konsumenteninformation v. Amazon [2016], Case C-191/15, par. 73-80. That the Rome II Regulation is not applicable to data privacy issues is clear from art. $1(2)(\mathrm{g})$ of the that Regulation. The applicability of the Rome I Regulation in data privacy issues has not been explored by the Court prior to this case. The Court has not offered a clear justification why a clause determining the law applicable to a contract does not affect the data privacy issues attached to it. One might reasonably assume that this is related to the wide scope of application of art. 4(1) of the Data Protection Directive. It seems, namely, that art. 4(1) of the Data Protection Directive covers data privacy issues in their entirety, including the possibility of contractual determination of the law applicable. Since art. 4(1) of the Data Protection Directive does not provide for such a contractual determination of the law applicable, it must be concluded that such contractual clauses are simply not allowed and, therefore, the Rome I Regulation cannot be called into application. That view seems to be consistent with the major goal pursued by art. 4(1) of the Data Protection Directive, namely the non-circumvention of EU data privacy law by clauses that might designate as applicable the law of a country with less stringent data privacy stipulations. See in that line Kartheuser, I. and Klar, M. (2014) Wirksamkeitskontrolle von Einwilligungen auf Webseiten Anwendbares Recht und inhaltliche Anforderung im Rahmen gerichtlicher Überprüfungen. Zeitschrift für Datenschutz, 4(10) pp. 500-505. Piltz, C. (2012) Rechtswahlfreiheit im Datenschutzrecht? Kommunikation E Recht, 15(10) pp. 640644 , considers data protection law to fall within art. 9 of the Rome I Regulation (overriding mandatory provisions) and, therefore, also suggests that a contractual circumvention of art. 4(1) of the Data Protection Directive shall not be possible. Despite the interesting argumentation, this opinion cannot be accepted without reservations. In excluding data protection law from the scope of the Rome I Regulation, the Court of Justice did not argue along these lines. 
The question whether such a specific jurisdictional regime was necessary and whether the established bases of jurisdiction provide for a reasonable and effective solution will be the subject of the analysis to follow.

\section{IS ART. 79(2) OF THE GDPR NECESSARY?}

\subsection{THE SHEVILL IMPACT AND DOCTRINAL REACTIONS}

A brief overview of the jurisdictional regime for online data privacy violations under the Brussels Ia Regulation must necessarily start from the decision of the Court of Justice of the European Union (CJEU) in the Shevill case. ${ }^{17}$ Although the case does not per se refer to online violations of data protection, it is the first one where the CJEU was called upon to examine the functioning of the Brussels jurisdictional regime in a scenario of ubiquitous personality infringements. In sum, the case revolved around the complaint of Fiona Shevill, domiciled in England, against a newspaper established in France that published an article linking Fiona Shevill to a drug case. The bulk of the newspapers containing the article that Fiona Shevill found to be defaming for her was distributed in France (237.000 of them). A considerably lower number had been distributed in other Member States (15.500 of them), and eventually only 230 papers made it to England. Fiona Shevill decided to sue the French newspaper in England, and the main question that the CJEU had to tackle was whether, under the Brussels jurisdictional rules, the English Courts could indeed adjudicate over the dispute.

In resolving this problem, the CJEU remained consistent with its previous case law regarding international judicial jurisdiction over tort cases, ${ }^{18}$ declaring once more that, apart from being allowed to sue at Courts of the domicile of the defendant, ${ }^{19}$ the victim of an alleged tort shall be able to sue either in the place where the event giving rise to the damage took place or in the place where the damage occurred. ${ }^{20}$ The Court went on to accept that this basic scheme shall remain applicable to personality

\footnotetext{
Fiona Shevill v. Presse Alliance SA [1994], Case C-68/93.

18 Most prominently the Bier v. Mines de potasse d'Alsace [1976], Case C-21/76.

19 Art. 4 REGULATION (EU) No 1215/2012 OF THE EUROPEAN PARLIAMENT AND OF THE COUNCIL of 12 December 2012 on jurisdiction and the recognition and enforcement of judgments in civil and commercial matters (recast). Official Journal of the European Union (2012/L 351/1) 20 December. Available from: http://eur-lex.europa.eu/ legal-content/EN/TXT/PDF/?uri=CELEX:32012R1215\&from=EN:PDF [Accessed 7 June 2017].

20 Bier v. Mines de potasse d'Alsace [1976], Case C-21/76, par. 14-19.
} 
infringements committed via mass media publications, ${ }^{21}$ even more so because in such cases the event giving rise to the damage, namely the publication of the infringing information, will usually (but not always) coincide the domicile of the defendant, thus stripping the victim of a potential jurisdictional basis. ${ }^{22}$ By allowing the victim to sue in each country where the alleged infringing material was distributed, the Court tried to establish an additional forum that shall be in a (procedurally) better position to adjudicate over ubiquitous personality disputes than the Courts of the domicile of the defendant. ${ }^{23}$ Based on this better procedural position, the Court limited the extent of the jurisdiction awarded to the forum of the place where the damaged occurred only within the limits of its own territory.

Whether one agrees with the outcome of the Shevill case ${ }^{24}$, or not, ${ }^{25}$ the dogmatic consistency of the ruling with the basic jurisdictional foundations of the Brussels regime cannot be disputed. In justifying the formulation of the jurisdictional basis at the courts of the country where the alleged victim suffered the damage in his/her personality rights, the Court explained that this extension of the available fora is justified by the axiom of sound administration of justice, which is the basic reason for the existence of the special rule of jurisdiction for tort cases (nowadays art. 7(2) of the Brussels Ia Regulation). ${ }^{26}$

The ruling of the CJEU in Shevill has functioned as the starting point of the discussion on how to treat, from an adjudicatory jurisdiction point of view, the problem of violations of personality rights via the Internet.

While all possible variations have been proposed in legal literature, ${ }^{27}$

${ }^{21}$ Fiona Shevill v. Presse Alliance SA [1994], Case C-68/93, par. 23.

22 Fiona Shevill v. Presse Alliance SA [1994], Case C-68/93, par. 24-27.

23 Fiona Shevill v. Presse Alliance SA [1994], Case C-68/93, par. 31.

${ }^{24}$ In that direction among others Huber, P. (1996) Persönlichkeitsschutz gegenüber Massenmedien im Rahmen des Europäischen Zivilprozeßrechts. Zeitschrift für Europäisches Privatrecht, 4(2) pp. 295-313, Wagner, G. (1998) Ehrenschutz und Pressfreiheit im europäischen Zivilverfahrens- und Internationalen Privatrecht. Rabels Zeitschrift für ausländisches und internationales Privatrecht, 62(2) pp. 243-285.

25 Among others Coester-Waltjen, D. (1999) Internationale Zuständigkeit bei Persönlichkeitsrechtsverletzungen. In: Festschrift für Rolf A. Schütze, Munich: C.H. Beck, pp. 175-187.

${ }_{26}$ Fiona Shevill v. Presse Alliance SA [1994], Case C-68/93, par. 31.

27 An exhaustive presentation of the different opinions expressed on the matter goes beyond the scope of the current contribution. For a neat summary of the academic proposals on how to treat personality torts over the Internet within the premises of the Brussels jurisdictional regime see Marton, E. (2016) Violations of Personality Rights through the Internet: Jurisdictional Issues under European Law. Baden-Baden: Nomos Verlag; Chawley Park, Cumnor Hill, Oxford: Hart Publishing, pp. 201-231. 
from also upholding the Shevill case law for Internet related personality violations $^{28}$ to abandoning them in favour of a plaintiff's forum ${ }^{29}$ or in favour of a targeting test, ${ }^{30}$ it has not been disputed that the existing jurisdictional rules of the Brussels regime provided an adequate basis (even if modifications of the existing case law have been proposed as necessary) to accommodate online violations of personality rights, including privacy. ${ }^{31}$

\subsection{UPDATING SHEVILL: EDATE AND MARTINEZ CASE LAW}

The definitive answer on whether the Brussels jurisdictional regime can accommodate personality violations over the Internet has been given by the CJEU in the joined eDate and Martinez cases. ${ }^{32}$

Both cases share a privacy background. In eDate, a web portal established in Austria reported on a crime committed by a person domiciled in Germany. The person was convicted for the crime but has lodged an appeal against the conviction. In order to force the web portal to desist from reporting the issue, the person linked to the crime brought an action before the German courts, claiming that the web portal shall be forced to refrain from using his full name when reporting about him in connection with the crime committed. In Martinez, French actor Olivier Martinez and his father brought an action before the French courts against MGN, a company established in England, because in the website of the Sunday Mirror, operated by MGN, there was a report on their private lives accompanied by pictures without their consent.

The CJEU was thus given the chance to examine the applicability of its previous Shevill case law in an Internet context. Inspired by the findings of AG Cruz Villalón, ${ }^{33}$ the Court found the Shevill case law not completely

28 See for example Stone P. (2006) EU Private International law. Harmonization of Laws. 2nd ed. Cheltenham, UK; Northampton MA: Edward Elgar, 2006, pp. 93-94.

29 Kubis, S. (1999) Internationale Zuständigkeit bei Persönlichkeits- und Immaterialgüterrechtsverletzungen. Bielefeld: Verlag Ernst und Werner Giesing, pp. 153-176.

30 Most characteristically Reymond, M. (2013) Jurisdiction in case of personality torts committed over the Internet: a proposal for a targeting test. Yearbook of Private International Law, 14 pp. 205-246.

31 In urging the European legislator to regulate in a more comprehensive way the private international law issues related to personality rights Hess, B. (2015) The Protection of Privacy in the Case Law of the CJEU. In: Burkhard Hess and Christina Mariottini (eds.) Protecting Privacy in Private International and Procedural Law and by Data Protection. BadenBaden: Nomos Verlag, pp. 112-113, suggests that such a future regulation shall be tailored on the Brussels Ia Regulation and in the way the CJEU has interpreted its provisions.

32 eDate Advertising GmbH v. X and Olivier Martinez v. MGN Limited [2011], joint Cases C-509/09 and C-161/10. 
satisfactory for Internet related privacy violations. ${ }^{34}$ It came to that conclusion after performing a scrutiny of the characteristics of online communications. Although printed mass media can also be distributed in a variety of countries, Internet publications, due to the incredible speed and geographical penetration of the dissemination, marginalise the significance of the place of distribution (named as a major connecting factor under the Shevill case law) and maximises the scale of the exposure of individuals to violations of their personality. ${ }^{35}$

In view of that, the Court performed a revision of the Shevill case law. After declaring that the particularities of Internet communications make necessary the existence of a jurisdictional basis, independent from the domicile of the defendant, where the victim of the alleged privacy violation can claim protection for the full scale of infringement, the Court decided that this place is to be found in the Member State of the "centre of the interests" of the alleged victim. ${ }^{36}$

In sum, after the eDate and Martinez decision, the alleged victim of an online privacy violation could sue the perpetrator in the following places:

- regarding the full extent of the damage in the Courts either of the domicile of the defendant/perpetrator ${ }^{37}$ or in the Courts of the victim's/plaintiff's centre of interests, which in the majority of the cases (but not necessarily always) will coincide with the victim's/plaintiff's domicile; ${ }^{38}$

- in cases where the domicile of the defendant/perpetrator does not coincide with the place of distribution, ${ }^{39}$ the victim/plaintiff can sue also in the courts of the Member State of the distribution for the full

33 Opinion of AG Cruz Villalón in joint Cases eDate Advertising GmbH v. X and Olivier Martinez v. MGN Limited [2011], C-509/09 and C-161/10, par. 56-67. Although the Court did not exactly adopt the jurisdictional ground proposed by the AG Villalón, in adapting the Shevill case law for Internet related cases shared his view on the necessity of doing so.

34 eDate Advertising GmbH v. X and Olivier Martinez v. MGN Limited [2011], joint Cases C-509/09 and C-161/10, par. 46.

35 eDate Advertising GmbH v. X and Olivier Martinez v. MGN Limited [2011], joint Cases C-509/09 and C-161/10, par. 47.

36 eDate Advertising GmbH v. X and Olivier Martinez v. MGN Limited [2011], joint Cases C-509/09 and C-161/10, par. 48 .

37 Under art. 4 of REGULATION (EU) No 1215/2012 OF THE EUROPEAN PARLIAMENT AND OF THE COUNCIL of 12 December 2012 on jurisdiction and the recognition and enforcement of judgments in civil and commercial matters (recast). Official Journal of the European Union (2012/L 351/1) 20 December. Available from: http://eur-lex.europa. eu/legal-content/EN/TXT/PDF/?uri=CELEX:32012R1215\&from=EN:PDF [Accessed 7 June 2017]. 
extent of the damage;

- last, but not least, the victim can still make use of the Shevill case law, allowing him/her to sue in each country where his/her personal information has been illegally processed, albeit only to the extent of the damage suffered in each of these countries.

The decision created polarised reactions. Some commentators considered that it was a step in the right direction, ${ }^{40}$ claiming that by creating a jurisdictional basis that allows the victim of an alleged online privacy violation to sue in the courts of the Member State in which the centre of his/her interests are located, it strikes a fairer balance between the victim and the perpetrator. Other commentators praised the readiness of the CJEU to adapt the jurisdictional provisions of the Brussels regime to the particularities of online communication, ${ }^{41}$ while others were very sceptical towards it, raising a series of legitimate concerns. ${ }^{42}$

Indeed, the ruling of the CJEU in eDate and Martinez signals a stark departure from the very fundamental principles of the jurisdictional scheme of the Brussels Ia Regulation. Adapting the principles of a legal instrument per se shall not be viewed as a problem. What is really problematic with the $e$ Date and Martinez decision is that it ignores the compelling reasons that led to the adoption of the jurisdictional principles that it has dismantled without providing convincing arguments that this should have been the case.

It must not be forgotten that the rules of jurisdiction of the Brussels Ia

38 Pursuant to art. 7 (2) of REGULATION (EU) No 1215/2012 OF THE EUROPEAN PARLIAMENT AND OF THE COUNCIL of 12 December 2012 on jurisdiction and the recognition and enforcement of judgments in civil and commercial matters (recast). Official Journal of the European Union (2012/L 351/1) 20 December. Available from: http://eur-lex.europa.eu/legal-content/EN/TXT/PDF/?uri=CELEX:32012R1215\&from=EN: pdf[Accessed 7 June 2017], as interpreted in the eDate and Martinez ruling.

39 For example, a data controller with a statutory seat in Member State A illegally posts personal information of the victim via the website of a subsidiary company established in Member State B and running its website in that Member State (Member State B).

40 Most notably, Hess, B. (2012) Der Schutz der Privatsphäre im Europäischen Zivilverfahrensrecht. Juristen Zeitung, 67(4) pp. 189-193.

41 Bogdan, M. (2013) Website Accessibility as Basis for Jurisdiction Under the Brussels I Regulation in View of New Case Law of the ECJ. In: Dan Jerker B. Svantesson and Stan Greenstein (eds.) Internationalisation of Law in the Digital Information Society. Copenhagen: Ex Tuto Publishing, pp. 159-172, esp. p. 167.

42 See among others Heinze, C. (2011) Surf global, sue local! Der europäische Klägergerichtsstand bei Persönlichkeitsrechtsverletzungen im Internet. Europäische Zeitschrift für Wirtschaftsrecht, 22(24) pp. 947-950, Mankowfski P. (2016) In: Ulrich Magnus and Peter Mankowfski (eds.) Brussels Ibis Regulation-Commentary. Köln: Verlag Dr. Otto Schmidt KG, pp. 323-328. 
Regulation are based on the principle of "actor sequitur forum rei" established in art. 4 of that Regulation. ${ }^{43}$ The adoption of "actor sequitur forum rei" was not a random choice but has a very strong justification dating back to the adoption of the Brussels Convention. The jurisdictional provisions of the Brussels regime and especially the jurisdictional basis of the domicile of the defendant share an existential bond with the provisions that refer to the recognition and enforcement of judgements. ${ }^{44}$ Simply put, the simplification of the recognition and enforcement of foreign civil judgements between the Member States of the $\mathrm{EU}^{45}$ is a clear procedural advantage of the plaintiff, who is the hopeful beneficiary of the recognition and enforcement. The "actor sequitur forum rei" principle aims to counterpoise this procedural advantage by offering a chance to the defendant to procedurally defend him/herself on equal terms, ${ }^{46}$ given that in international litigation the risks for the procedural rights of the defence are higher than those in plainly domestic cases. ${ }^{47}$

43 For the content and the meaning of the "actor sequitur forum rei" principle within the Brussels jurisdictional regime see Hess, B. (2010) Europäisches Zivilprozessrecht. Heidelberg: C.F. Müller Verlag, pp. 265-271.

44 That this is indeed the case see Hallstein, W. (1964) Angleichung des Privatund Prozessrechts in der Europäischen Wirtschaftsgemeinschaft. Rabels Zeitschrift für ausländisches und internationales Privatrecht, 28(2) pp. 211-231, esp. 223 where he notes: "[...] Die Vereinfachung und Beschleunigung des Exequaturverfahrens allein war jedoch nicht ausreichend, um allen Anforderungen zu genügen, die an ein wirksames Verfahren der Rechtsverfolgung innerhalb eines einheitlichen Wirtschaftsraumes gestellt werden müssen. Man denke zum Beispiel an die Fälle, in denen die Vollstreckung im Anerkennungsstaat verweigert wird, weil in diesem Staat ein bereits ergangenes Urteil unvereinbar ist mit dem Urteil, um dessen Exequatur nachgesucht wird, oder weil im Anerkennungsstaat zwischen denselben Personen und in derselben Sache ein Verfahren schwebt. Wollte man die Zahl dieser Fälle verringern, so musste auch die territoriale Zuständigkeit durch das neue Abkommen unmittelbar geregelt werden $[\ldots]^{\prime \prime}$.

45 Simplification that reached so far as to abolish the exequatur procedure from the Brussels Ia Regulation. See on that Kramer, X.E. (2013) Cross-Border Enforcement and the Brussels I-bis Regulation: Towards a New Balance between Mutual Trust and National Control over Fundamental Rights. Netherlands International Law Review, 60 pp. 343 - 373, Geimer, R. Unionsweite Titelvollstreckung ohne Exequatur nach der Reform der Brüssel I-Verordnung. In: Festschrift für Rolf A. Schütze, Munich: C.H. Beck, pp. 109 - 121, Isidro, M.R. On the Abolition of Exequatur. In: Burkhard Hess and Maria Bergström and Eva Stroskrubb (eds.) EU Civil Justice: Current Issues and Future Outlook, Oxford: Hart Publishing, pp. 283298.

46 In that sense the "actor sequitur forum rei principle" is the jurisdictional mirroring of the nonrecognition ground referring to the judgements that are given in default of appearance of art. 45 Brussels Ia. See in that regard the ruling of the Court in Autoteile v. Malhé [1985], Case C-220/84, par. 15: "[...] According to article 2, persons domiciled in a Contracting State are to be sued in the courts of that State. That provision is intended to protect the rights of the defendant; it serves as a counterpoise to the facilities provided by the Convention with regard to the recognition and enforcement of foreign judgements [...]".

${ }^{47}$ On that, see the Jenard, P. Report on the Convention on jurisdiction and the enforcement of judgments in civil and commercial matters. Official Journal of the European Union (1979/C 59/1) 05 March. Available from: http://aei.pitt.edu/1465/1/commercial_report_jenard_C59 _79.pdf [Accessed 7 June 2017], p. 18. 
Although that does not mean that the domicile of the defendant is the only jurisdictional base to be found in the Brussels Ia Regulation, it still puts that jurisdictional ground in the place of the basic rule. ${ }^{48}$ Save for the exclusive jurisdictional bases of the Brussels Ia Regulation, ${ }^{49}$ the domicile of the defendant shall be the starting point of any international dispute in the $\mathrm{EU},{ }^{50}$ including those that refer to online violations of privacy. That very fact shall also guide the interpretation of the additional bases of jurisdiction, especially those located in art. 7, where the special jurisdiction for torts is also accommodated.

By this is meant that the interpretation of the jurisdictional bases located in art. 7 of the Brussels Ia Regulation shall be restrictive, so that they do not go beyond their true scope of application, as this is to be found in the reasons that justified their adoption. ${ }^{51}$ As it is clear both from the recitals of the Brussels Ia Regulation ${ }^{52}$ and from an unbreakable chain of CJEU decisions, ${ }^{53}$ the reason for adopting art. 7 in general and the jurisdictional base for torts in art. $7(2)$ is not the protection of the victims of torts. Art. 7 is neutral when it comes to protecting the individual interests of the parties. ${ }^{54}$ The real reason for adopting art. 7 was the efficacious administration of justice, based on the proximity

48 See Group Josi v UGIC [2000], Case C-412/98, par. 35.

49 Established in art. 24 of REGULATION (EU) No 1215/2012 OF THE EUROPEAN PARLIAMENT AND OF THE COUNCIL of 12 December 2012 on jurisdiction and the recognition and enforcement of judgments in civil and commercial matters (recast). Official Journal of the European Union (2012/L 351/1) 20 December. Available from:http://eurlex.europa.eu/legal-content/EN/TXT/PDF/?uri=CELEX:32012R1215\&from=EN:PDF [Accessed 7 June 2017].

50 The actor sequitur forum rei has even survived within the jurisdictional scheme of sections 3, 4 and 5 of REGULATION (EU) No 1215/2012 OF THE EUROPEAN PARLIAMENT AND OF THE COUNCIL of 12 December 2012 on jurisdiction and the recognition and enforcement of judgments in civil and commercial matters (recast). Official Journal of the European Union (2012/L 351/1) 20 December. Available from:http://eur-lex.europa.eu/ legal-content/EN/TXT/PDF/?uri=CELEX:32012R1215\&from=EN:PDF [Accessed 7 June 2017] even if that happened in the form of equal alternative to the otherwise plaintiff favourable jurisdictional grounds established thereof.

51 In that context see Handte $v$ Traitements [1992], Case C-26/91, par. 14.

52 Recitals 15 and 16 REGULATION (EU) No 1215/2012 OF THE EUROPEAN PARLIAMENT AND OF THE COUNCIL of 12 December 2012 on jurisdiction and the recognition and enforcement of judgments in civil and commercial matters (recast). Official Journal of the European Union (2012/L 351/1) 20 December. Available from:http://eur-lex.europa.eu/ legal-content/EN/TXT/PDF/?uri=CELEX:32012R1215\&from=EN:PDF [Accessed 7 June 2017].

53 Among others Tessili v Dunlop [1976], Case C-12/76, par. 13, Dumez France v Hessische Landesbank [1989], Case C-220/88, par. 17 and most notably Besix v Kretzschmar [2001], Case C-256/00, par. 31, where the Court stated: "[...] The reason for the adoption of the jurisdictional rule ... was concern for sound administration of justice and efficacious conduct of proceedings [...]".

54 For that conclusion see Pointier, J.A. and Burg, E. (2004) EU Principles of Jurisdiction and Recognition and Enforcement of Judgements in Civil and Commercial Matters according to the case law of the European Court of Justice. The Hague: TMC Asser Press, p. 160. 
of the bases of jurisdiction found in this article to the procedural elements of a certain case. ${ }^{55}$ By inserting a non-existent element of protection of the plaintiff in art. 7 in eDate and Martinez, the CJEU went far further than the scope of this article without providing convincing reasons for doing so.

In addition, the fact that the adoption of the domicile of defendant as the basic rule of jurisdiction within the Brussels is directly connected with the idea of providing the procedural balance that was described above means that the plaintiff shall not, in principle, acquire any procedural advantages in the territory of adjudicatory jurisdiction. Favouring the plaintiff both in terms of adjudicatory jurisdiction, by uncontrollably creating fora actoris, and in terms of simplifying the recognition and enforcement of judgements would turn the Brussels Ia Regulation from an instrument that aims to facilitate the protection of human rights of all EU citizens to an instrument that protects only the rights of the plaintiffs.

There are many other points of the eDate and Martinez ruling that raise legitimate questions, ${ }^{56}$ such as, for example, the additional problems that stem from the unreasonable multiplication of jurisdictional bases created by the CJEU. Not only forum shopping in disputes regarding online privacy violations is not only easier now, but one also cannot ignore the possibility of different Member State courts rendering contradictory decisions for the same subject matter, undermining legal certainty in the European judicial space. ${ }^{57}$ Nonetheless, a detailed and exhaustive discussion of the vices and virtues of the eDate and Martinez ruling goes beyond the scope of the current contribution.

What is really important to take away from the brief examination of that case is that the CJEU was ready to go as far as to dismantle the basic jurisdictional principles of the Brussels Ia Regulation, and even risk the existence of legal certainty, in order to afford a strong protection

55 That this is the underlying principle especially of art. 7 (2) see Kropholler, J. and Von Hein, J. (2011) Europäisches Zivilprozessrecht-Kommentar zu EuGVO, Lugano-Übereinkommen 2007, EuVTVO, EuMVVO und EuGFVO. Frankfurt am Main: Verlag Recht und Wirtschaft GmBH, p. 201.

56 Dickinson, A. (2012) By Royal Appointment: No Closer to an EU Private International Law Settlement? [blog entry] 24 October. Conflict Of Laws.net. Available from: http://conflictof laws.net/2012/by-royal-appointment-no-closer-to-an-eu-private-international-law-

settlement/ [Accessed 07 June 2017], has neatly summarized 7 points of critique for the ruling.

${ }^{57}$ Schmidt, J. (2015) Rechtssicherheit im europäischen Zivilverfahrensrecht. Tübingen: Mohr Siebeck, pp. 133-138 presents some interesting argumentation in that direction. 
to the victims of online privacy violations. In view of the above, one might legitimately raise doubts on whether an additional jurisdictional rule for privacy violations, like the one established in art. 79(2) of the GDPR, was necessary.

\subsection{AN UNEASY RELATIONSHIP}

The question becomes even more reasonable if one examines the content of art. 79(2) of the GDPR, ${ }^{58}$ which states:

"Proceedings against a controller or a processor shall be brought before the courts of the Member State where the controller or processor has an establishment. Alternatively, such proceedings may be brought before the courts of the Member State where the data subject has his or her habitual residence, unless the controller or processor is a public authority of a Member State acting in the exercise of its public powers."

The very first point that makes the relationship of GDPR art. 79(2) with the Brussels Ia Regulation uneasy is the blurry scope of application of GDPR art. 79(2) of the GDPR does not include any indication on whether it repeals the jurisdictional provisions of the Brussels Ia Regulation or whether it just complements them. While an assumption on the basis of the axiom "lex specialis derogat lege generali" would militate in favour of the assumption that art. 79(2) replaces the jurisdictional rules of Brussels Ia for privacy violations, recital 147 of the GDPR puts such an assumption in question. In a rather sibyllic and cryptic manner, recital 147 of the GDPR states:

"Where specific rules on jurisdiction are contained in this Regulation, in particular as regards proceedings seeking a judicial remedy including compensation, against a controller or processor, general jurisdiction rules such as those of Regulation (EU) No 1215/2012 of the European Parliament and of the Council should not prejudice the application of such specific rules."

58 REGULATION 2016/679 OF THE EUROPEAN PARLIAMENT AND OF THE COUNCIL of 27 April 2016 on the protection of natural persons with regard to the processing of personal data and on the free movement of such data, and repealing Directive 95/46/EC (General Data Protection Regulation). Official Journal of the European Union (2016/L 119/1) 04 May. Available from: http://ec.europa.eu/justice/data-protection/reform/files/regulation_oj_ en.pdf [Accessed 7 June 2017]. 
That seems to imply that art. 79(2) does not replace the jurisdictional grounds of the Brussels Ia Regulation, but rather that the two systems shall coexist, albeit not on an equal basis. While the jurisdictional rules of the Brussels Ia Regulation are still in force for online privacy violations, they will not be applied in all cases that they contradict the jurisdictional grounds of GDPR art. 79(2) ${ }^{59}$ What can lead to a contradiction between art. 79(2) and Brussels Ia shall probably be examined on a case by case basis for each one of the individual jurisdictional grounds of the Brussels Ia Regulation. Apart from being a rather tedious task, discovering a contradiction between legal rules can also be proven very controversial. It is probably the CJEU that will be called upon to solve the problem in the future, but the doubts and uncertainty caused in the meantime might be detrimental to the administration of justice within the EU.

If, for example, the most obvious candidate for a parallel application with GDPR art. 79(2), namely art. 7(2) of the Brussels Ia Regulation, is to be considered, a very unpleasant scenario will automatically occur. If one looks at the interpretation of art. 7(2) of the Brussels Ia Regulation in the eDate and Martinez ruling, a contradiction between the two does not seem likely. ${ }^{60}$ Applied together, these two provisions [GDPR art. 79(2) and Brussels Ia art. 7(2)] would create a multitude of different fora in favour of the data subject. In such a scenario, the data subject will be able to sue in regard to the full extent of the damage suffered, at his/her discretion, in one of the following places: before the courts of the Member State of the domicile of the controller or processor (under art. 4 of the Brussels Ia Regulation), before the courts of the Member State of the centre of the data subject's interests (under art. 7(2) as the latter was interpreted by the CJEU in eDate and Martinez), before the courts of the Member State of the establishment of the controller or processor (under art. 79(2) of the GDPR) or, finally, before the courts of the Member State of the data

\footnotetext{
${ }^{59}$ The German version of recital 147 makes use of the term "nicht entgegenstehen", which implies that the non-application of the Brussels Ia jurisdictional rules shall be the outcome of their contradiction with the jurisdictional rules of art. 79(2) GDPR. If the jurisdictional grounds of Brussels Ia are not contradictory to those of art. 79(2) GDPR, then they shall apply in parallel. See Werkmeister, C. (2017). In: Peter Gola (ed.) DatenschutzGrundverordnung VO (EU) 2016/679-Kommentar. Munich: C.H. Beck, p. 730, who notes: "[...] Erwägungsgrund 147 gibt vor, dass die allgemeinen Vorschriften über die Gerichtsbarkeit, wie sie etwa in der EuGVVO enthalten sind, der Anwendung der spezifischen Vorschriften nach der DSGVO nicht entgegenstehen sollen. Sofern die besonderen Gerichtsstände nach der EuGVVO neben den Gerichtsständen nach Art. 79 Abs. 2 anwendbar bleiben, stehen diese den Vorgaben der DSGVO jedenfalls nicht entgegen [...]".

${ }^{60}$ Ibid.
} 
subject's habitual residence (under art. 79(2) of the GDPR). In addition, the data subject will still be able to sue in each individual Member State were his/her data became illegally available, but only for the extent of the damage suffered in each state.

That such an unreasonably overextended jurisdictional privilege of the data subject will cause a long series of problems does not need much analysis. It is just an example of how unthoughtful the legislator has been in dealing with jurisdictional problems within the GDPR, while ignoring at the same time the decades old Brussels regime.

In order to avoid such or similar absurd jurisdictional outcomes as the one described above, it is submitted that a parallel application of GDPR art. 79(2) and Brussels Ia art. 7(2) shall be denied. The contradiction of Brussels Ia art. 7(2) with GDPR art. 79(2) might not be derived directly from their jurisdictional grounds but from their different underlying principles: if it still holds true that the purpose of art. 7(2) of the Brussels Ia Regulation is not to favour the plaintiff, but to foster the better administration of justice, ${ }^{61}$ while on the contrary, art. 79(2) of the GDPR aims to empower the position of the data subject in terms of judicial jurisdiction, ${ }^{62}$ one could admit that there is a certain degree of incompatibility between the two, given that their underlying principles are mutually exclusive and cannot be pursued at the same time. Indeed, if one aims to procedurally favour one of the parties, such an aim cannot be compromised with the aim to form neutral and generally fair procedural conditions and justice guarantees. In other words, doing too much justice for one of the parties automatically means that one cannot do justice for both. Art. 79(2) of the GDPR must necessarily prevail, as art. 7(2) would otherwise prejudice its application.

This incompatibility test based not on the jurisdictional grounds per se but on the underlying principles of the competing jurisdictional rules might offer general guidance in clarifying the scope of application of GDPR art. 79(2) and the jurisdictional grounds of Brussels Ia Regulation.

For example, another interesting scenario might be that the parties agree

61 Supra notes 52, 53 and $54 .$.

62 That conclusion might be justified from a systematic interpretation of art. 79(2) of the GDPR. Art. 79 is located in chapter VIII of the GDPR, a chapter that aims to strengthen the legal protection of the data subjects in the EU and, therefore, it is not neutral in its assessment of the procedural interests of the parties. Simply put like all the other remedies of chapter VIII of the GDPR, art. 79 wants to empower the data subject in terms of enforcement of his/her rights derived from the GDPR. 
to submit a data privacy dispute before a commonly designated court. Can Brussels Ia art. 25 and GDPR art. 79(2) be compatible? Are, in other words, jurisdictional clauses for data privacy disputes allowed? The underlying principle of art. 25 is to protect the contractual autonomy of the parties, ${ }^{63}$ while GDPR art. 79(2) aims to empower the procedural position of the data subject. Empowered procedural position and contractual autonomy are not always incompatible, if one takes the example of how Brussels Ia has treated the jurisdictional clauses in consumer cases. ${ }^{64}$ Despite the strong procedural protection awarded to consumers, jurisdictional agreements are, nonetheless, possible, albeit with certain formal and material limitations. Contractual autonomy is in this way not sacrificed in favour of procedural protection; it is just being put in a certain frame. ${ }^{65}$ By the same token, one could argue that contractual autonomy shall not be deemed incompatible with strong data privacy protection, if jurisdictional agreements related to data privacy violations respect the limits set by the combined application of Brussels Ia art. 25 and GDPR art. 79(2). Art. 25 of Brussels Ia will provide the formal limits of such jurisdictional agreements (for example art. 25 will provide that jurisdictional agreements shall in general be in written form), while the limits that stem from GDPR art. 79(2) will refer to the content of such agreements. Jurisdictional agreements in data privacy cases shall namely not deprive the data subject of the jurisdictional grounds prescribed in GDPR art. 79(2). ${ }^{66}$ In other words, jurisdictional agreements that favour the data subject by expanding the available (under GDPR art. 79(2) grounds of jurisdiction will still be permissible.

The same line of argumentation might also prove helpful in solving the problem of tacit prorogation of jurisdiction. The CJEU has made clear in its Česká podnikatelská v. Michal Bilas ruling ${ }^{67}$ that a party might abolish his/her jurisdictional privileges through a tacit prorogation of jurisdiction. ${ }^{68}$ That might be a dangerous precedent for data subjects, who unbeknownst

\footnotetext{
${ }_{63}$ See Anterist v. Crédit Lyonnais [1986], case C-22/85, par. 14.

${ }^{64}$ See art. 19 REGULATION (EU) No 1215/2012 OF THE EUROPEAN PARLIAMENT AND OF THE COUNCIL of 12 December 2012 on jurisdiction and the recognition and enforcement of judgments in civil and commercial matters (recast). Official Journal of the European Union (2012/L 351/1) 20 December. Available from: http://eur-lex.europa.eu/ legal-content/EN/TXT/PDF/?uri=CELEX:32012R1215\&from=EN:PDF [Accessed 7 June 2017].

${ }^{65}$ For the notion of framed autonomy in EU Civil Law see Reich, N. (2014) General Principles of EU Civil Law. Cambridge; Antwerp; Portland: intersentia, pp. 18-36.

${ }^{66}$ See Feiler, L. and Forgó, N. (2017) EU-Datenschutz-Grundverordnung-Kurzkommentar. Vienna: Verlag Österreich, p. 336.

${ }^{67}$ Česká podnikatelská pojištovna as, Vienna Insurance Group v. Michal Bilas [2010], Case C-111/09.
} 
to them might lose the protection of GDPR art. 79(2). In that case, party autonomy cannot be combined with the aim to procedurally favour the data subjects and, therefore, art. 26 of the Brussels Ia Regulation must be deemed incompatible with GDPR art. 79(2) and thus non-applicable on data privacy violations.

Further problems from the scope of application of GDPR art. 79(2) might arise not only from its compatibility (or lack of such) with the Brussels Ia jurisdictional regime but also from the general problems attached to the applicability of the GDPR overall. The GDPR delegates a nonnegligible amount of issues to the national laws of the Member States. ${ }^{69}$ That leads to the question whether GDPR art. 79(2) shall cover also such data privacy disputes that stem from national regulations or whether it shall be deemed non-applicable in such cases. If one gives gravity to the wording of art. 79(1) of the GDPR, art. 79 in toto seems to represent the civil procedural incarnation of the rights afforded to the data subjects through the GDPR, ${ }^{70}$ but not to those afforded to them through Member State legislation. If that is true, then the jurisdictional grounds of GDPR art. 79(2) shall only come into play for violation of privacy rights that stem from the GDPR, but not for those privacy rights that stem from Member State legislation. Practically, that will create two tiers of jurisdictional grounds for data privacy violations in the EU: for data privacy rights that stem from the GDPR, data subjects will benefit from both the jurisdictional grounds of GDPR art. 79(2) and those of Brussels Ia, to the extent that they can be applied in parallel, while for data privacy rights that stem from national codifications the only set of jurisdictional rules available is that of the Brussels Ia. If the GDPR wanted to unify the level of protection across the EU Member States, GDPR art. 79(2) does not seem to be heading in that direction, as it creates two diverse types of data subjects: namely those that will benefit from the combined jurisdictional grounds of GDPR

68 Safe for the jurisdictional grounds that are established in Brussels Ia Regulation art. 24. See Česká podnikatelská pojištoona as, Vienna Insurance Group v. Michal Bilas [2010], Case C-111/09, par. 24-26.

${ }^{69}$ See in more detail Kühling, J. and Martini, M. (2016) Die Datenschutz-Grundverordnung: Revolution oder Evolution im europäischen und deutschen Datenschutzrecht? Europäische Zeitschrift für Wirtschaftsrecht, 27(12) pp. 448-454.

70 Art. 79(1) states: Without prejudice to any available administrative or non-judicial remedy, including the right to lodge a complaint with a supervisory authority pursuant to Article 77, each data subject shall have the right to an effective judicial remedy where he or she considers that his or her rights under this Regulation have been infringed as a result of the processing of his or her personal data in non-compliance with this Regulation (emphasis added). 
art. 79(2) and Brussels Ia Regulation and those that can only resort to the Brussels Ia regulation. For legal practitioners across the EU, the constant question of which set of jurisdictional grounds shall be applicable will also not be a pleasant task.

The second point, beyond the scope of application, that makes the relationship of GDPR art. 79(2) and the Brussels Ia Regulation uneasy refers to the jurisdictional grounds established in the former. Art. 79(2) of the GDPR expands the dismantling of the basic jurisdictional principles of the Brussels Ia Regulation initiated by the CJEU with its decision in $e$ Date and Martinez. Apart from being disproportionately favourable for the data subject/plaintiff, ${ }^{71}$ the jurisdictional grounds provided for by art. 79(2) of the GDPR extend well beyond their Brussels Ia counterparts.

Instead of allowing the data subject to sue at the domicile of the defendant along the lines of Brussels Ia Regulation art. 4, GDPR art. 79(2) opens the doors of litigation before the courts of the Member State where the data controller or processor retains an establishment. If the rulings of the CJEU in Google Spain ${ }^{72}$ and Weltimmo ${ }^{73}$ have clarified something, that is the readiness of the Court not only to flexibly adapt its legal reasoning to Internet situations ${ }^{74}$ but, most prominently, also its willingness to marginalise the nexus of the contacts of the establishment with a Member State for the purpose of extending the scope of data protection law. ${ }^{75}$ In Google Spain, the Court went as far as to declare that

${ }^{71}$ It must be reminded here that while the GDPR is not neutral towards the interests of the parties when providing the data subjects the procedural remedies of art. 79, the Brussels Ia Regulation aims to establish a very delicate balance that shall keep the plaintiff and the defendant in an equal procedural footing when they are trying to judicially protect their fundamental rights. In terms of the Brussels Ia Regulation see Hess, B. (2015) Unionsrechtliche Synthese: Mindesstandards und Verfahrensgrundsätze im acquis communitaire/Schlussfolgerungen für European Principles of Civil Procedure. In: Matthias Weller and Christoph Althammer (eds.) Mindesstandards im europäischen Zivilprozessrecht. Tübingen: Mohr Siebeck, pp. 221-235, esp. 223 where he states: "[...] ine eigenständige Prinzipienebene enthält das europäische Zivilverfahrensrecht jedoch bereits heute: Sie besteht zunächst auf der Ebene des Primärrechts in den Vorgaben der Marktfreiheiten und der Grundrechte ... Bei der Interpretation der EU-Sekundärrechtsakte zum internationalen Zivilprozessrecht hat der Gerichtshof eigenständige Grundsätze und Regelungskonzepte entwickelt: effektiver Zugang zur Justiz, Beklagtenschutz im Zuständigkeitsrecht, Urteilsfreizügigkeit, wechselseitiges Vertrauen in die Justizsysteme anderer EU-Mitgliedstaaten [...]".

72 Google Spain SL v. Agencia Española de Protección de Datos (AEPD) [2014], Case C-131/12.

73 Weltimmo s. r. o. v. Nemzeti Adatvédelmi és Információszabadság Hatóság [2015], Case C-230/14.

${ }^{74}$ For a positive assessment of that part of the Google Spain decision in that regard see the comment of Karg (2014) EuGH: Löschungsanspruch gegen Google-"Recht auf Vergessen". Zeitschift für Datenschutz, 4(7) pp. 350-361, esp. pp. 359-361.

75 For a critical assessment see Kartheuser, I and Schmitt, F. (2016) Der Niederlassungsbegriff und seine praktischen Auswirkungen. Anwendbarkeit des Datenschutzrechtes eines Mitgliedstaats auf ausländische EU-Gesellschaften. Zeitschrift für Datenschutz, 6(4) pp. 155159. 
the establishment must not actively take part in data processing activities in order for EU data protection law to be applicable; ${ }^{.76}$ in Weltimmo, it substantially lowered the level of what constitutes "effective and stable arrangements" within a Member State and accepted that a mere website that addresses its activities to a Member State different than that of the domicile of the controller or processor can suffice for the existence of an establishment in the meaning of art. 4(1)(a) of the Data Protection Directive, even if the nexus of contacts between the website and the Member State are rather low. ${ }^{77}$ There seems to be no doubt that the notion of establishment in GDPR art. 79(2) is taken from the same term used in GDPR art. 3, which itself is the direct descendant of art. 4(1)(a) of the Data Protection Directive that gave rise to the aforementioned case law and, subsequently, that it must be interpreted along the same lines. ${ }^{78}$

Translated in jurisdictional terms, the combined effect of the Google Spain and Weltimmo notion of establishment will create a questionable and probably dysfunctional jurisdictional environment: not only will forum shopping be maximised $^{79}$ but also the very broad interpretation of the notion of establishment by the Court will create an extremely remote or even trivial connection between the courts of the Member State that will be deemed as having adjudicatory power and the dispute over which they shall adjudicate, raising doubts about the quality of the final outcome of the decision. Decisions related to data privacy violations and issued by Member State courts designated through such weak jurisdictional grounds as the establishment of the data controller prescribed in GDPR art.79(2) will still be qualified to circulate within the EU based on the privileged recognition and enforcement regime of the Brussels Ia Regulation. It must be reminded here that the privileged recognition and enforcement regime of the Brussels Ia Regulation is founded

76 Google Spain SL v. Agencia Española de Protección de Datos (AEPD) [2014], Case C-131/12, par. 52-55.

77 Weltimmo s. r. o. v. Nemzeti Adatvédelmi és Információszabadság Hatóság [2015], Case C-230/14, par. 29-33.

78 Recital 22 REGULATION (EU) 2016/679 OF THE EUROPEAN PARLIAMENT AND OF THE COUNCIL of 27 April 2016 on the protection of natural persons with regard to the processing of personal data and on the free movement of such data, and repealing Directive 95/46/EC (General Data Protection Regulation). Official Journal of the European Union (2016/L 119/1) 04 May. Available from: http://ec.europa.eu/justice/data-protection/ reform/files/regulation_oi_en.pdf [Accessed 7 June 2017]., Martini, M. (2017) In: Boris Paal and Daniel Pauly (eds.) Datenschutz-Grundverordnung. Munich, Germany: C.H. Beck, p. 720.

79 Feiler, L. and Forgó, N. (2017) EU-Datenschutz-Grundverordnung-Kurzkommentar. Vienna: Verlag Österreich, p. 335. 
on the respect of certain procedural guarantees in favour of the defendant, one of the most important being the procedural balance that the Brussels regime tries to secure by its, more or less, fair and reasonable jurisdiction rules. Given that the generous to the data subject/plaintiff jurisdictional grounds of GDPR art. 79(2) neutralise such jurisdictional guarantees as those achieved by the Brussels Ia jurisdictional regime, the circulation of judgements related to online data privacy violations will severely distort the trust of EU citizens in the administration of justice within the common judicial area, even if none of the refusal grounds of Brussels Ia Regulation art. 45 can be invoked. In addition, one cannot overlook the concerns raised by the unreasonable multiplication of jurisdictional grounds created by the possibility of a data controller or processor being established in more than one Member States, which will further undermine the notion of legal certainty within the judicial system of the EU.

The alternative jurisdictional ground of the habitual residence of the data subject provided for by GDPR art. 79(2) does little, if anything, to bring the jurisdictional grounds of that provision closer to the Brussels regime. By allowing the data subject to sue in the courts of his/her habitual residence GDPR art. 79(2) creates another plaintiff jurisdiction to the detriment of the "actor sequitur forum rei" principle that lies in the centre of the Brussels Ia jurisdictional scheme. Although such jurisdictional rules favourable to the plaintiff are not unknown to the system of the Brussels Ia Regulation, ${ }^{80}$ one must always take into account the exceptional character of such plaintiff jurisdiction rules as well as the compelling reasons that justified their adoption. The jurisdictional privileges awarded to the insurance policy holder, employee and consumer are justified by their weak socio-economical position in relation to their contractual counterparts. ${ }^{81}$ By improving their jurisdictional position, the Brussels Ia Regulation is trying to counterbalance the negotiating deficiency that is inherent for these particular stakeholders. While that might be true for several privacy cases as well, the wide definition

80 See art. 11, art. 18 and art. 21 REGULATION (EU) No 1215/2012 OF THE EUROPEAN PARLIAMENT AND OF THE COUNCIL of 12 December 2012 on jurisdiction and the recognition and enforcement of judgments in civil and commercial matters (recast). Official Journal of the European Union (2012/L 351/1) 20 December. Available from:http://eurlex.europa.eu/legal-content/EN/TXT/PDF/?uri=CELEX:32012R1215\&from=EN:PDF [Accessed 7 June 2017].

81 See most characteristically Société Bertrand v. Ott [1978], Case C-150/77, par. 13 and among others Hill, J. (2008) Cross-border Consumer Contracts. Oxford; New York: Oxford University Press, pp. 75-76. 
of the subject matter of data protection law can render almost everyone a data controller. That means that in a rather considerable number of privacy cases the parties will litigate from a socio-economical equal basis. It seems, thus, that the creation of a plaintiff jurisdiction for data subjects cannot be so easily justified. ${ }^{82}$

It shall also be mentioned that the insertion of a plaintiff jurisdiction based not on the data subject's domicile but on that of his/her habitual residence might also be proven controversial. Although an autonomous interpretation of the concept of habitual residence is not completely foreign to EU civil procedural law $^{83}$ and the CJEU might probably provide one in the context of GDPR art. 79(2) in the future, its flexible and wide nature will once again lower the nexus of contacts between a privacy case and the Member State where such a case shall be adjudicated. Simply put, establishing a habitual residence is easier than establishing a domicile and, subsequently, data subjects will once more benefit from a relaxed jurisdictional rule, without being sure that such a procedural advantage is completely justified.

\section{INSTEAD OF AN EPILOGUE: A FEW LINES ON THE IMPACT OF GDPR ART. 79(2) IN NON-EU PARTIES}

The previous analysis focused on the impact of the jurisdictional rules of GDPR art. 79(2) within the EU. It seems fair to conclude this contribution with a few lines on the possible impact of GDPR art. 79(2) outside of the EU.

The adoption of the GDPR signals, among many other things, an official declaration from the EU that its privacy regulatory model is aggressively claiming a wide extraterritorial application. ${ }^{84}$

Art. 3 offers an extended territorial scope to the GDPR, ${ }^{85}$ especially in Internet related activities, and that extended territorial scope is also

82 For a different assessment see Brkan, M. (2015) Data protection and European private international law: observing a bull in a China shop. International Data Privacy Law, 5(4) pp. 257-278.

83 See for example the ruling of the CJEU in $A$ [2009], Case C-523/07, par. 8. Martini, M. (2017) In: Boris Paal and Daniel Pauly (eds.) Datenschutz-Grundverordnung. Munich, Germany: C.H. Beck, pp. 720-721, after noting that the use of the term habitual residence in art. $79(2)$ GDPR has been rather careless ("ohne Bedacht"), goes on to suggest that its interpretation shall be conducted autonomously by the CJEU and in line with the interpretation of the same term found in Council Regulation (EC) No 2201/2003 of 27 November 2003 concerning jurisdiction and the recognition and enforcement of judgments in matrimonial matters and the matters of parental responsibility, repealing Regulation (EC) No 1347/2000. Official Journal of the European Union (2003/L 338/1) 23 December. Available from: http://eur-lex.europa.eu/legal-content/EN/TXT/PDF/?uri=CELEX:32003R2201\&from=EN: PDF [Accessed 7 June 2017]. 
afforded to the jurisdictional grounds of GDPR art. 79(2). Quite remarkably, while the Member States vehemently opposed the application of the Brussels Ia Regulation in non-EU cases, ${ }^{86}$ they displayed a rare unanimity and raised no objections when the GDPR declared its own jurisdictional regime applicable to almost the entire Internet. ${ }^{87}$

One must not be surprised if legal orders that do not share the same privacy concerns as those dominant in the $\mathrm{EU}^{88}$ react, not always positively, to such wide jurisdictional claims. The US might pose a good example in that regard. It is after all a commonality that the US has a distinct and, in many ways, different approach to data privacy in comparison to the EU. ${ }^{89}$ In addition, the US retains a firm stance in defending their unique approach to judicial jurisdiction over Internet cases ${ }^{90}$ that is not necessarily compatible with the Brussels regime ${ }^{91}$ and even more so with the rules provided for in GDPR art. 79(2).

In the (concomitant with data privacy) field of defamation law the US has been rather proactive in defending their notion of freedom of speech over the preference that the European courts have shown for the right to personality. Their reaction was triggered by the unfortunate jurisdictional outcome in the Bin Mahfouz v. Ehrenfeld case. ${ }^{92}$ In sum, Dr. Rachel Ehrenfeld,

84 Kuner, C. (2014) The European Union and the Search for an International Data Protection Framework. Groningen Journal of International Law, 2(1) pp. 55-71, looks critical at the tendency of the EU to impose its privacy model on other jurisdictions instead of creatively contributing to the creation of better global privacy standards.

85 See among others Klar, M. (2017) In: Jürgen Kühling and Benedikt Büchner (eds.) Datenschutz-Grundverordnung-Kommentar. Munich: C.H. Beck, pp. 99-123.

86 See European Parliament, Session document, A7-0219/2010, pp. 3-15.

87 Despite its crucial importance extraterritoriality has not raised any serious discussions during the preparation of the GDPR. For a similar assessment see Svantesson, D.J.B. (2013) Extraterritoriality in Data Privacy Law. Copenhagen: Ex Tuto Publishing, p. 106.

88 Kuner, C. (2009) An international legal framework for data protection: Issues and prospects. Computer Law \& Security Review, 25 pp. 307-317, offers a very good insight into the complexity created by a common international data privacy model and explores what are the mechanisms that can lead to a convergence of the different regional approaches.

89 For a comparative approach to the US privacy model see Moshell, R. (2005) ... And then there was one: The outlook for a self-regulatory United States amidst a global trend toward comprehensive data protection. Texas Law Review, 37 pp. 357-432, Whitman, J.Q. (2004) The Two Western Cultures of Privacy: Dignity versus Liberty. The Yale Law Journal, 113 pp. 1151-1221.

90 For a well-founded doctrinal reaction to the overarching impact of the EU jurisdictional system see Bradford, A. (2012) The Brussels Effect. Northwestern University Law Review, 107(1) pp. 1-67.

91 For a comparative view on the US and EU approaches to judicial jurisdiction over Internet related cases see Chen, C. (2004) United States and European Union Approaches to Internet Jurisdiction and their Impact on E-Commerce. University of Pennsylvania Journal of International Economic Law, 25(1) pp. 423-454.

92 Mahfouz \& Ors v Ehrenfeld \& Anor [2005] EWHC 1156 (Q.B.). 
an American writer, published a book on international terrorism in which she reported that Khalid bin Mahfouz, a Saudi billionaire, assisted al Qaeda to deliver the 9/11 attacks. Only 23 books of Dr. Ehrenfeld's have been distributed in England. Based on the distribution of these 23 books, Khalid bin Mahfouz brought a defamation action before the English courts. Even though bin Mahfouz was not an English citizen and despite the extremely small number of books distributed in that jurisdiction, the English courts decided that they had international jurisdiction to adjudicate. In a default judgement, since Dr. Ehrenfeld did not appear before the English courts, they awarded damages to bin Mahfouz and enjoined Dr. Ehrenfeld from further publishing the allegedly defamatory statements in England. Despite her efforts before the state Courts of New York, Dr. Ehrenfeld has been unable to invalidate the English decision.

The undeniably chilling effects of such libel tourism tactics ${ }^{93}$ to the freedom of speech alerted the US legislator, and not long after the outcome of the Ehrenfeld case was finalised the US adopted the Speech $\mathrm{Act}^{94}$. Simply put, the Speech Act blocks the recognition and enforcement of foreign judgements, the content of which does not respect freedom of speech in a manner similar to that of the American Constitution. ${ }^{95}$

If the example of the Speech $\mathrm{Act}^{96}$ is to remind us of something, it is the value of reasonable jurisdictional claims. While it has been substantially supported that enforceability in an international context shall not be strictly tied to jurisdictional claims, ${ }^{97}$ the existential relationship between

93 Hartley, T. (2010) "Libel Tourism" and Conflict of Laws. International and Comparative Law Quarterly, 59 pp. 25-38, explains neatly why private international law rules, including jurisdiction, shall secure a balance between freedom of speech and personality rights.

94 Securing the Protection of our Enduring and Established Constitutional Heritage Act 2010. United States of America. Washington D.C.: 111th United States Congress. In English. Before the adoption of the Speech Act in Federal Level several US States have enacted similar legislation at a state level. See for example Libel Terrorism Protection Act enacted in the State of New York, 2008 N.Y. Laws ch. 66, § 3 [codified at N.Y. C.P.L.R. 302, 5304 (McKinney 2008)]. For an analysis of that act and the impact of libel tourism in the US see Feldman, M. (2010) Putting breaks on libel tourism: Examining the effects test as a basis for personal jurisdiction under New York's Libel Terrorism Protection Act. Cardozo Law Review, 31(6) pp. 2458-2489.

95 For a brief analysis of the provisions of the Act see Congressional Research Service (2010), The Speech Act: The Federal Response to "Libel Tourism". 16 September. Available from: https://fas.org/sgp/crs/misc/R41417.pdf [Accessed 7 June 2017] and in more detail Rosen, M. (2012) The Speech Act's Unfortunate Parochialism: Of Libel Tourism and Legitimate Pluralism. Virginia Journal of International Law, 53(1) pp. 99-126.

96 The acronym of the act offers a good indication of its content. The full title is: Securing the Protection of our Enduring and Established Constitutional Heritage Act.

97 Svantesson, D.J.B. (2015) A Jurisprudential Justification for Extraterritoriality in (Private) International Law. Santa Clara Journal of International Law, 13(2) pp. 517-571. 
adjudicatory jurisdiction and international enforcement shall not be ignored. ${ }^{98}$ The Speech Act is a good example of the negative impact of unreasonable jurisdiction claims, even if one remains adamant in questioning the value of international enforceability, since it has forced a jurisdiction traditionally friendly to foreign judgments such as that of the US $S^{99}$ to become completely hostile and refuse to recognise and enforce a certain category of foreign judgments.

It seems that the European legislator has wilfully ignored the message delivered by the adoption of the Speech Act when preparing art. 79(2) of the GDPR. It remains to be seen if that was a wise decision. ${ }^{100}$

\section{LIST OF REFERENCES}

[1] Baumgartner, S. (2017) The External Dimensions of the European Law of Civil Procedure-A Transatlantic Perspective. In: Burkhard Hess (ed.) Der Europäische Gerichtsverbund-Die internationale Dimension deseuropäischen Zivilverfahrensrechts. Bielefeld: Verlag Ernst und Werner Gieseking GmbH, pp. 165-199.

[2] Bogdan, M. (2013) Website Accessibility as Basis for Jurisdiction Under the Brussels I Regulation in View of New Case Law of the ECJ. In: Dan Jerker B. Svantesson and Stan Greenstein (eds.) Internationalisation of Law in the Digital Information Society. Copenhagen: Ex Tuto Publishing, pp. 159-172.

[3] Bradford, A. (2012) The Brussels Effect. Northwestern University Law Review, 107(1), pp. 1-67.

\footnotetext{
See Section 4102(b)(1) of the Speech Act which states: "In general.--Notwithstanding any other provision of Federal or State law, a domestic court shall not recognize or enforce a foreign judgment for defamation unless the domestic court determines that the exercise of personal jurisdiction by the foreign court comported with the due process requirements that are imposed on domestic courts by the Constitution of the United States".

99 That the American courts show a deep respect in the principle of international comity and are usually open to recognize and enforce foreign judgements, as well as that the Speech act has changed that attitude see Baumgartner, S. (2017) The External Dimensions of the European Law of Civil Procedure-A Transatlantic Perspective. In: Burkhard Hess (ed.) Der Europäische Gerichtsverbund-Die internationale Dimension des europäischen Zivilverfahrensrechts. Bielefeld: Verlag Ernst und Werner Gieseking GmbH, pp. 165-199. He makes, therefore, the argument that this change of attitude after the Speech Act shall function as an incentive for an enhanced cooperation in the field of recognition and enforcement of judgments, via the Hague Judgements Project.

${ }^{100}$ Current indications do not support an optimistic assessment here. The press has already reported that after the adoption of the Speech Act, which currently only affects defamation but not data privacy cases, European lawyers are disguising defamation cases as privacy litigation in order to circumvent the application of the Speech ACT. See Roberts, J. (2016) Privacy Laws Pose New Threat to Free Speech [blog entry] 19 January. Fortune-Tech. Available from: http://fortune.com/2016/01/19/libel-privacy-tourism/ [Accessed 7 June 2017]. By making privacy litigation easier GDPR art. 79(2) might maximize the scale of "Privacy Tourism" and, therefore, force the US to react accordingly.
} 
[4] [4] Brkan, M. (2015) Data protection and European private international law: observing a bull in a China shop. International Data Privacy Law, 5(4) pp. 257-278.

[5] Bygrave, L. (2000) Determining Applicable Law pursuant to European Data Protection Legislation. Computer Law \& Security Report, 16, pp. 252-257.

[6] Chen, C. (2004) United States and European Union Approaches to Internet Jurisdiction and their Impact on E-Commerce. University of Pennsylvania Journal of International Economic Law, 25(1), pp. 423-454.

[7] Coester-Waltjen, D. (1999) Internationale Zuständigkeit bei Persönlichkeitsrechtsverletzungen. In: Festschrift für Rolf A. Schütze, Munich: C.H. Beck, pp. 175-187.

[8] Congressional Research Service (2010), The Speech Act: The Federal Response to "Libel Tourism". 16 September. Available from: https://fas.org/sgp/crs/misc/R41417.pdf [Accessed 7 June 2017].

[9] Dickinson, A. (2012) Royal Appointment: No Closer to an EU Private International Law Settlement? [blog entry] 24 October. Conflict Of Laws.net. Available from: http:// www.conflictoflaws.net/2012/by-royal-appointment-no-closer-to-an-eu-privateinternational-law-settlement/ [Accessed 7 June 2017].

[10] Dougan, M. (2008) The Treaty of Lisbon 2007: Winning Minds not Hearts. Common Market Law Review, 45(3), pp. 617-703.

[11] EU Council. The Hague Programme: Strengthening Freedom, Security and Justice in the EU. Official Journal of the European Union, (2005/C 53/1) 03 March. Available from: http://eur-lex.europa.eu/legal-content/EN/TXT/PDF/?uri=CELEX:52005XG0303 (01)\&from=EN:PDF [Accessed 7 June 2017].

[12] EU Council. The Stockholm Programme - An open and secure Europe serving and protecting citizens. Official Journal of the European Union (2010/C 115/1) 05 May. Available from: http://eur-lex.europa.eu/legal-content/EN/TXT/PDF/?uri=OJ:C:2010: 115:FULL\&from=en:PDF [Accessed 7 June 2017].

[13] Feiler, L. and Forgó, N. (2017) EU-Datenschutz-Grundverordnung-Kurzkommentar. Vienna: Verlag Österreich.

[14] Feldman, M. (2010) Putting breaks on libel tourism: Examining the effects test as a basis for personal jurisdiction under New York's Libel Terrorism Protection Act. Cardozo Law Review, 31(6), pp. 2458-2489.

[15] Geimer, R. Unionsweite Titelvollstreckung ohne Exequatur nach der Reform der Brüssel I-Verordnung. In: Festschrift für Rolf A. Schütze, Munich: C.H. Beck, pp. 109-121. 
[16] Goebel, R.J. (2011) The European Union and the Treaty of Lisbon. Fordham International Law Journal, 34(5), pp. 1251-1268.

[17] Hallstein, W. (1964) Angleichung des Privat- und Prozessrechts in der Europäischen Wirtschaftsgemeinschaft. Rabels Zeitschrift für ausländisches und internationales Privatrecht, 28(2), pp. 211-231.

[18] Harpaz, G. and Herman, L. (2008) The Lisbon Reform Treaty: Internal and External Implications. European Journal of Law Reform, 10(4), pp. 431-436.

[19] Hartley, T. (2010) „Libel Tourism“ and Conflict of Laws. International and Comparative Law Quarterly, 59, pp. 25-38.

[20] Heinze, C. (2011) Surf global, sue local! Der europäische Klägergerichtsstand bei Persönlichkeitsrechtsverletzungen im Internet. Europäische Zeitschrift für Wirtschaftsrecht, 22(24), pp. 947-950.

[21] Hess, B. (2010) Europäisches Zivilprozessrecht. Heidelberg: C.F. Müller Verlag.

[22] Hess, B. (2012) Der Schutz der Privatsphäre im Europäischen Zivilverfahrensrecht. Juristen Zeitung, 67(4), pp. 189-193.

[23] Hess, B. (2015) The Protection of Privacy in the Case Law of the CJEU. In: Burkhard Hess and Christina Mariottini (eds.) Protecting Privacy in Private International and Procedural Law and by Data Protection. Baden-Baden: Nomos Verlag, pp. 112-113.

[24] Hess, B. (2015) Unionsrechtliche Synthese: Mindesstandards und Verfahrensgrundsätze im acquis communitaire/Schlussfolgerungen für European Principles of Civil Procedure. In: Matthias Weller and Christoph Althammer (eds.) Mindesstandards im europäischen Zivilprozessrecht. Tübingen: Mohr Siebeck, pp. 221-235.

[25] Hill, J. (2008) Cross-border Consumer Contracts. Oxford; New York: Oxford University Press.

[26] Huber, P. (1996) Persönlichkeitsschutz gegenüber Massenmedien im Rahmen des Europäischen Zivilprozeßrechts. Zeitschrift für Europäisches Privatrecht, 4(2), pp. 295-313.

[27] Isidro, M.R. On the Abolition of Exequatur. In: Burkhard Hess and Maria Bergström and Eva Stroskrubb (eds.) EU Civil Justice: Current Issues and Future Outlook, Oxford: Hart Publishing, pp. 283-298.

[28] Jenard, P. Report on the Convention on jurisdiction and the enforcement of judgments in civil and commercial matters. Official Journal of the European Union (1979/C 59/1) 05 March. Available from: http://aei.pitt.edu/1465/1/commercial_report_jenard_C59_79. pdf [Accessed 7 June 2017]. 
[29] Karg (2014) EuGH: Löschungsanspruch gegen Google-"Recht auf Vergessen”. Zeitschift für Datenschutz, 4(7), pp. 350-361.

[30] Kartheuser, I and Schmitt, F. (2016) Der Niederlassungsbegriff und seine praktischen Auswirkungen. Anwendbarkeit des Datenschutzrechtes eines Mitgliedstaats auf ausländische EU-Gesellschaften. Zeitschrift für Datenschutz, 6(4), pp. 155-159.

[31] Kartheuser, I. and Klar, M. (2014) Wirksamkeitskontrolle von Einwilligungen auf Webseiten Anwendbares Recht und inhaltliche Anforderung im Rahmen gerichtlicher Überprüfungen. Zeitschrift für Datenschutz, 4(10), pp. 500-505.

[32] Klar, M. (2017) In: Jürgen Kühling and Benedikt Büchner (eds.) DatenschutzGrundverordnung-Kommentar. Munich: C.H. Beck, pp. 99-123.

[33] Kramer, X.E. (2013) Cross-Border Enforcement and the Brussels I-bis Regulation: Towards a New Balance between Mutual Trust and National Control over Fundamental Rights. Netherlands International Law Review, 60, pp. 343-373.

[34] Kropholler, J. and Von Hein, J. (2011) Europäisches Zivilprozessrecht-Kommentar zu EuGVO, Lugano-Übereinkommen 2007, EuVTVO, EuMVVO und EuGFVO. Frankfurt am Main: Verlag Recht und Wirtschaft GmBH.

[35] Kubis, S. (1999) Internationale Zuständigkeit Persönlichkeits- und Immaterialgüterrechtsverletzungen. Bielefeld: Verlag Ernst und Werner Giesing.

[36] Kühling, J. and Martini, M. (2016) Die Datenschutz-Grundverordnung: Revolution oder Evolution im europäischen und deutschen Datenschutzrecht? Europäische Zeitschrift für Wirtschaftsrecht, 27(12), pp. 448-454.

[37] Kuner, C. (2009) An international legal framework for data protection: Issues and prospects. Computer Law \& Security Review, 25, pp. 307-317.

[38] Kuner, C. (2014) The European Union and the Search for an International Data Protection Framework. Groningen Journal of International Law, 2(1), pp. 55-71.

[39] Lanaerts, K. (2012) Die EU - Grundrechtecharta: Anwendbarkeit und Auslegung. Europarecht, 47, pp. 3-18.

[40] Landau, E.C. (2008) A New Regime of Human Rights in the EU? European Journal of Law Reform, 10(4), pp. 557-575.

[41] Mankowfski P. (2016) In: Ulrich Magnus and Peter Mankowfski (eds.) Brussels Ibis Regulation-Commentary. Köln: Verlag Dr. Otto Schmidt KG, pp. 323-328.

[42] Martini, M. (2017) In: Boris Paal and Daniel Pauly (eds.) Datenschutz-Grundverordnung. Munich, Germany: C.H. Beck, p. 720. 
[43] Marton, E. (2016) Violations of Personality Rights through the Internet: Jurisdictional Issues under European Law. Baden-Baden: Nomos Verlag; Chawley Park, Cumnor Hill, Oxford: Hart Publishing.

[44] Moerel, L. (2011) Back to basics: when does EU data protection law apply? International Data Privacy Law, 1(2), pp. 92-110.

[45] Moerel, L. (2011) The long Arm of EU data protection law: Does the Data Protection Directive apply to processing of personal data of EU citizens by websites worldwide? International Data Privacy Law, 1(1), p. 28.

[46] Moshell, R. (2005) ... And then there was one: The outlook for a self-regulatory United States amidst a global trend toward comprehensive data protection. Texas Law Review, 37, pp. 357-432.

[47] Pache, E. (2002) Eine Verfassung für Europa - Krönung oder Kollaps der europäischen Integration? Europarecht, 37, pp. 767-784.

[48] Pache, E. and Rösch, F. (2009) Die neue Grundrechtsordnung der EU nach dem Vertrag von Lissabon. Europarecht, 44 , pp. 769-790.

[49] Pech, L. (2011) The Institutional Development of the EU Post - Lisbon: A case of plus ca change...?, UCD Dublin European Institute Working Paper 11 - 5, December 2011.

[50] Piltz, C. (2012) Rechtswahlfreiheit im Datenschutzrecht? Kommunikation \& Recht, 15(10), pp. 640-644.

[51] Pointier, J.A. and Burg, E. (2004) EU Principles of Jurisdiction and Recognition and Enforcement of Judgements in Civil and Commercial Matters according to the case law of the European Court of Justice. The Hague: TMC Asser Press.

[52] Reich, N. (2014) General Principles of EU Civil Law. Cambridge; Antwerp; Portland: intersentia.

[53] Reymond, M. (2013) Jurisdiction in case of personality torts committed over the Internet: a proposal for a targeting test. Yearbook of Private International Law, 14, pp. 205-246.

[54] Roberts, J. (2016) Privacy Laws Pose New Threat to Free Speech [blog entry] 19 January. Fortune-Tech. Available from: http://fortune.com/2016/01/19/libel-privacytourism/ [Accessed 7 June 2017].

[55] Rosen, M. (2012) The Speech Act's Unfortunate Parochialism: Of Libel Tourism and Legitimate Pluralism. Virginia Journal of International Law, 53(1), pp. 99-126. 
[56] Sarmiento, D. (2013) Who's afraid of the Charter? The Court of Justice, National Courts and the new Framework of Fundamental Rights Protection in Europe. Common Market Law Review, 50(3), pp. 1267-1304.

[57] Savin, A. (2013) EU Internet Law. Cheltenham; Northampton: Edward Elgar.

[58] Schmidt, J. (2015) Rechtssicherheit im europäischen Zivilverfahrensrecht. Tübingen: Mohr Siebeck.

[59] Stone P. (2006) EU Private International law. Harmonization of Laws. 2nd ed. Cheltenham, UK; Northampton MA: Edward Elgar, 2006, pp. 93-94.

[60] Svantesson, D.J.B. (2013) A "layered approach" to the extraterritoriality of data privacy laws. International Data Privacy Law, 3(4), pp. 278-286.

[61] Svantesson, D.J.B. (2013) Extraterritoriality in Data Privacy Law. Copenhagen: Ex Tuto Publishing.

[62] Svantesson, D.J.B. (2015) A Jurisprudential Justification for Extraterritoriality in (Private) International Law. Santa Clara Journal of International Law, 13(2), pp. 517571.

[63] Svantesson, D.J.B. (2016) Against "Against Data Exceptionalism". Masaryk University Journal of Law and Technology, 10(2), pp. 200-211.

[64] Terhechte, J.P. (2008) Der Vertrag von Lissabon: Grundlegende Verfassungsurkunde der europäischen Rechtsgemeinschaft oder technischer Änderungsvertrag? Europarecht, 43, pp. 143-190.

[65] Wagner, G. (1998) Ehrenschutz und Pressfreiheit im europäischen Zivilverfahrensund Internationalen Privatrecht. Rabels Zeitschrift für ausländisches und internationales Privatrecht, 62(2), pp. 243-285.

[66] Werkmeister, C. (2017). In: Peter Gola (ed.) Datenschutz-Grundverordnung VO (EU) 2016/679-Kommentar. Munich: C.H. Beck, p. 730.

[67] Whitman, J.Q. (2004) The Two Western Cultures of Privacy: Dignity versus Liberty. The Yale Law Journal, 113, pp. 1151-1221.

[68] Woods, A.K. (2016) Against Data Exceptionalism. Stanford Law Review, 68(4), pp. 729789. 